\title{
ХУДОЖНІЙ ТЕКСТ ЯК МЕНТАЛЬНЕ УТВОРЕННЯ
}

\author{
ВАЛЕНТИНА КРАВЧЕНКО, НАТАЛЯ ЗУБЕЦЬ \\ Запорізький національний університет, Запоріжжя - Україна \\ TEKST ARTYSTYCZNY JAKO TWÓR MENTALNY \\ WALENTYNA KRAWCZENKO, NATALA ZUBEĆ \\ Narodowy Uniwersytet Zaporoski, Zaporoże — Ukraina
}

STRESZCZENIE. Przedmiotem rozważań w niniejszym artykule jest tekst artystyczny w aspekcie kognitywnym jako rezultat procesów mentalnych dotyczących reprezentacji, adaptacji, percepcji oraz utrwalania wiedzy ludzkiej. Powyższe zagadnienie badawcze rozpatrywane jest na konkretnym materiale literackim — twórczości wybitnego ukraińskiego pisarza Romana Fedoriwa.

\author{
ARTISTIC TEXT AS MENTAL FORMATION \\ VALENTYNA KRAVCHENKO, NATALYA ZUBETS \\ Zaporizhzhya National University, Zaporizhzhya - Ukraine.
}

\begin{abstract}
The author considers the artistic text in cognitive approach as a result of mental processes which concern representation, adaptation, perception and preservation of human knowledge. The problem is solved with a specific literary material-the oeuvre of a famous Ukrainian writer Roman Fedoriv.
\end{abstract}

$\mathrm{T}$

екст - одне 3 ключових понять у мовознавстві - досить тривалий час сприймався як особлива форма мови, найвищий ярус мовної системи. Коли в др. пол. ХХ ст. увага дослідників перемістилася з мовної системи на мовленнєву діяльність, текст почали розглядати як найважливішу комунікативну одиницю, що виконує функції спілкування, пізнання, впливу. Учені зауважили, що підходи до аналізу тексту не можуть бути однаковими. У виокремленій галузі мовознавства — текстолінгвістиці, - що вивчає подачу, сприйняття й розуміння текстів на основі формально-структурної, стилістичної та жанрової різноплановості в писемній, усній, друкованій, комп'ютерній формах, сьогодні склалася традиційна класифікація, сформувалося кілька підходів до вивчення цього складного й багатопланового явища мовної та позамовної дійсності. На зміну лінгвоцентричному й текстоцентричному напрямам вивчення тексту прийшли антропоцентричний та когнітивний, що в українському мовознавстві розробляють Ф. Бацевич, А. Загнітко, Л. Мацько, О. Селіванова та ін. Незважаючи на значні досягнення в галузі лінгвістики тексту, єдиного визначення цього ключового поняття поки що немає, натомість відомо більше 300 авторських дефініцій ${ }^{1}$ - від схематичних, на зразок: ,,текст = системність (побудова за встановленими моделями) + індивідуальність (безкінечна варіантність матеріальної форми)"’2 до узагальнювальних, як, напр., у терміноло-

${ }^{1}$ В. Е. Чернявская, Лингвистика текста: Поликодовость, интертекстуальность, интердискурсивность, Учеб. пособие, Москва 2009, с. 14.

${ }^{2}$ T. І. Должикова, I. В. Мілєв а, А. В. Ніктіна, Практикум з лінгвістики тексту, Навч.-метод. посібник, Луганськ 2011, с. 20. 
гічній енциклопедії: „цілісна семіотична форма лінгвопсихоментальної діяльності мовця, концептуально та структурно інтегрована, що служить прагматичним посередником комунікації й діалогічно вбудована до семантичного універсуму культури"з

3-поміж багатьох ознак тексту найбільша їхня кількість виявляється в художньому його різновиді: сукупність мовних засобів, естетичний вплив на свідомість і поведінку людини, вияв культури, інтелектуальної й духовної діяльності людини, засіб мовленнєвої діяльності, результат і спосіб пізнання тощо. Саме цей різновид тексту й обрано авторкою як актуальний об'єкт дослідження, оскільки в процесі його розгляду важливу роль відіграють ще й екстралінгвістичні умови створення та сприймання, адже автор має певні національно зумовлені ціннісні орієнтири, які репрезентують певну лінгвокультуру. У цьому сенсі вивчення тексту скеровується в когнітивному напрямі, що виходить за межі лінгвістики, й текст сприймається як проміжний компонент комунікації.

На наше переконання, художній текст (XT) як специфічно організований спосіб комунікації формує у свідомості адресата певну ментальну модель, що забезпечує розуміння його змісту. Ставимо за мету простежити етапи цього втілення, що матеріалізуються у творчості письменників, які є зразковими носіями національної культури, духовності.

Такою особистістю є український письменник, лауреат кількох літературних премій Роман Федорів (1930-2001). Творчість цього, за словами Я. Гояна, „славного співця рідного Прикарпаття, чесного хлібороба святого поля української літератури"4 вповні відкрилася читачам лише в умовах незалежної України, хоча ще за радянського часу його романи, зокрема Отчий світильник, посіли чільне місце в ряду найвищих художніх досягнень українського історичного роману. Літературна панорама видатного прозаїка сучасності складається 3 есе, оповідань, повістей, романів, значна частина яких була недоступна в часи тоталітарної системи, оскільки вони утверджували націєохоронні мотиви. Дослідники творчості Р. Федоріва (М. Ільницький, В. Качкан, Т. Салига та ін.) вбачають феноменальність творів митця у змістовій і світоглядній самобутності автора, а основними домінантами його прози вважають тонке відчуття України, української культури, малої батьківщини, національну специфіку ${ }^{5}$ I. Франко стверджував, що національну самобутність кожної літератури творять ,іiі питомий національний характер, iї оригінальні прикмети, основні особливості іiі народного гумору і народного пафосу, властивість їі вислову, літературного стилю, поетичної техніки <...>. Тільки той писатель може нині мати якесь значення, хто має і вміє цілій освіченій людськості сказати якесь своє слово в тих питаннях, що ворушать їі душею, та зразком сказати те слово в такій формі, яка б найбільше відповідала його національній вдачі",

Матеріалом цієї розвідки слугує останній прижиттєвий твір Р. Федоріва повість-триптих Micmepï з інших світів ${ }^{7}$, події якої переважно розгортаються на теренах рідного письменнику гуцульського краю - Прикарпатті. Народо-

3 О. Селіванова, Сучасна лінгвістика: термінологічна енц̧иклопедія, Полтава 2006, c. $599-600$.

${ }^{4}$ Я. Го я н, Слова співчуття і скорботи, [в:] „Дзвін”, 2001, № 4, с. 159.

${ }^{5}$ М. І ль ни ць к й , Два десятиліття поряд: До 75-річчя від дня народження Р. Федоріва, [в:] „Дзвін”, 2005, № 12, с. 131; В. К ач кан , Силове поле його душі: до 80-річчя Романа Федоріва, [в:] „Дзвін”, 2010, № 12, с. 134; Т. С а л и г а, Білий птах Романа Федоріва, [в:] „Молодь України" 1978, 28 лютого, с. 3.

${ }^{6}$ І. Ф ран ко, Зібрання творів у 50 m., Київ 1983, т. 31, с. 34.

${ }^{7}$ Р. Ф е д о р і в , Містерї̈ з інших світів, [в:] „Дзвін”, 2001, №№ 3-4. 
знавці, етнопсихологи стверджують, що залежно від того, в якій місцевості народилася людина, в неї формуються певні риси характеру, світовідчуттєві настанови ${ }^{8}$ Окремі етнічні групи мають відповідно локальну свідомість. У прикарпатському краї незвичайність природи, чарівність гір породжують нестримне відчуття краси, але цей край вимагає від людей сили, відваги, мужності, витривалості, щоб вижити. Залежність від милості природи відбивається на їхньому світосприйнятті, мисленні. Етнопсихологічний феномен, що являє собою спосіб мислення чи характер процесу мислення, називається ментальністю. Її серцевиною є духовна культура народу, а складниками - фольклор, звичаї, традиції, література, мистецтво, релігія, мова. В. Гумбольдт наголошував, що кожна мова описує навколо народу коло, до якого він належить, коло, з якого людина може вийти лише тоді, коли вона входить у коло іншої мови ${ }^{9}$. Відповідно мовна ментальність (ММ) певного етносу — це світосприйняття в категоріях і формах рідної мови, що поєднує інтелектуальні, вольові й духовні якості національного характеру в типових його рисах. Головними чинниками ММ $\epsilon$ соціокультурні фактори, що мінливі, а значить, і вона мінлива.

Мовними виявами національного світосприйняття можуть бути символи, міфологеми, архетипи, ключові слова епохи, стереотипи тощо. У розглядуваній повісті Р. Федоріва ці одиниці вербальної комунікації передають особливості духовної культури горян: захоплення магією, власне розуміння краси, добра, зла, домінування природного начала, волелюбність. Закоріненість письменника в специфічну етнографію, самобутність гірської природи допомогли створити яскраві персонажі: це горяни, які живуть у світі гірських чарів, хоча він для них реальний, зелейники, чарівники, мольфари, які мають особливий дар спілкування 3 природою, а також інтелігенція, звичайні чоловіки та жінки зі своїм особистим життям, світоглядом, характерами, які хоч і живуть у час телевізійний, просвітницький, усе ж вірять у гірські страхи, поговори про вовкулаків, казки про упирів та про блуди, карпатські міфи. Вони є носіями таких специфічних національних рис характеру, як кордоцентризм (побожність, сентиментальність, чуттєвість), антеїзм (злитість 3 природою), а також - очищення від рудиментів тоталітаризму. У кожній з трьох частин - свої персонажі, сюжетні лінії, але все обертається навколо одвічних понять: добро / зло, моральність / аморальність, чесність / безчестя, життя / смерть, духовність / бездуховність. Лейтмотивом повісті є думка: світ повний таємниць, і справа людини - відкривати їх чи проходити мимо.

Художній текст розглядають у зв'язку автор - текст - читач. Цей комунікативний ланцюжок відображає один із типів вербального спілкування, що позбавлений спонтанності. Творець тексту надає реципієнту вербалізовані знання, а він їх інтерпретує відповідно до власної концептуальної картини світу, тобто відбувається перехід від кодів мови до внутрішніх кодів інтелекту. Але взаємодія автора й читача буде повноцінною лише тоді, коли в них єдині фонові знання (однакові знання про реалії, культуру тощо). У цій статті актуалізуємо регіональні фонові знання, спільні для конкретної етнічно-мовної групи українців, що невіддільні від загальнолюдських і країнознавчих.

${ }^{8}$ О. Кульчч и ц к и й , Риси характерології украӥнського народу, [в:] Енциклопедія украӥнознавства, Загальна частина, репринтне відтворення видання 1949 р., Київ 1995, с. 8-19.

${ }^{9}$ В. Гумбольдт, О различии строения человеческих языков и его влиянии на духовное развитие человечества, [в:] В. А. Звегинцев, История языкознания XIX-XX веков в очерках и извлечениях, Москва 1984, с. 80. 
Діалог автора й читача розпочинається вже із заголовка твору. Уважається, що назва є першим знаком XТ. У цьому разі назва повісті-триптиху Micmepiї з інших світів є глибоко асоціативною, бо вже перше слово містерії (буквально „таємниці, таїнства” ${ }^{10}$ ) дотичне до ментальних уявлень про поєднання фантастичного з реальним, про драматичність подій; воно відображає авторський задум, що формулює один із персонажів повісті - журналіст, який уособлює автора: ... мені самому було цікаво поринати у потік народного життя, де перебували історія, легенди, казки, краса землі, зачаровані мистеитвом люди ${ }^{11}$. Згадуючи в назві інші світи, прозаїк передає філософську та естетичну інформацію про багатогранність буття й ніби провокує читача на пізнання земних і неземних тайн, самого себе. Колоритний персонаж повісті - гуцул-чарівник Ілько Цюцяк розмірковує: Світ не одновимірний... він глибокий ... стррашно й звабливо шукати в ньому дна. Як у душі людській... ${ }^{12}$. У кожній частині повісті-триптиху постає один із світів, створених людиною або природою: світ зла (частина 1. Дерево, щз пам'ятало зло), світ природи (частина 2. Змій, коронований у Гороnaxax), світ добра (частина 3. Кларнет із Лісу на піщзаних горбах).

Отже, заголовок у Р. Федоріва виконує ретроспективну функцію, бо відразу зацікавлює, інтригує, провокує асоціативну налаштованість читача на таємниці, дива.

Жанр триптиху не лише містить інформацію про структуру повісті, в якій три частини утворюють концептуальну й лінгвостилістичну єдність. Цифра „,3”, загалом троїстість нагадують читачеві про фольклорну символіку, а взаємовплив національної ментальності й народної творчості відзначено вже давно. Дефініцією триптих, а потім і сюжетно, автор проводить паралелі між багатовимірністю світу й античними уявленнями про три житла людей - Небо, Землю, Підземне царство, трьома основними константами міфопоетичного мікрокосму - чарівне, людське, природне, а також макрокосму — минуле, теперішнє, майбутнє $\epsilon^{13}$.

Описи таких вербально-паралінгвістичних явищ, як видіння, чарівні перетворення, замовляння, марення слугують тлом для зображення вчинків дійових осіб, зближують твір з окремими фольклорними жанрами. Автор вбудовує в композицію повісті реалістичні епізоди спілкування гуцулів-чародіїв 3 гадюками, відьомських чудес і чаклувань (кам'яна порча, заклинання на трой-зілля, зміїна ворожба), контактів земних людей з гірськими міфічними істотами Чугайстром, Паном над плазунами. У дусі кращих фольклорних традицій письменник подає символічні образи півня (символ Христа, який кличе із мороку до світла), груші (рідкісне подвійне сприйняття: зло і безпліддя — краса, надія і здоров'я $)^{14}$, що стають у повісті міфологемами. Деякі образи розкриваються за рахунок міфологічної реальності, що допускає перевтілення людини: напр., сільська відьма Анелька час від часу оберталася кішкою, птахою, щоб творити свої чорні справи; душі загиблих у Галичині під час другої світової війни італійських солдат перевтілилися в метеликів і пташок, щоб хоч через десятки років повернутися на батьківщину. А ось фрагмент палкої сповіді закоханої жін-

${ }^{10}$ Сучасний словник іншомовних слів, укл.: О. І. Скопнен ко, Т. В. Ци мбалюк, Київ 2006, с. 459-460.

${ }^{11}$ Р. Фе до о рі в , зазн. джерело, № 4, с. 3.

${ }^{12}$ Там само, с. 13

13 Энииклопедия символики и геральдики, [в:] Електронний pecypc: www.simbolarsum.ru/ index/php/число3 (10.02.2013).

${ }^{14}$ Там само. 
ки, змученої ревнощами, що нагадує плач як жанр народної творчості: Засліплений, зачумлений, оглушений, утомлений у хмільних ночах, ти, мій милий, відпливав від мене все далі й далі й губився твій слід у сірій мряці буденщини... й імені ти мого не чув, і голосу мого не чув, і росла я без тебе, а кругом був ліс, були трави, болота поліські, вітри північні не приносили від тебе звісток, а сонце спивало твої сліди на мураві.. я збирала їх у поділ, твої сліди, мій милий,клала їх собі в душу і виливала в слова. Ти об цім нічого не знаєщ, $і$ ні про щзо в мене не розпитуєш, мій милий 15 .

У мовній тканині повісті спостерігаємо реалізацію ментального лексикону й слововжитку, що виявляється і в мові автора, і в мовних партіях персонажів. Звичаї, норми повсякденного життя прикарпатців, гуцулів, географічні та історичні факти, описані Р. Федорівим, є трансляторами західноукраїнських реалій (артефактів), що вплітаються в загальноукраїнський контекст, однак формують систему цінностей у відповідному соціумі. Це передусім безеквівалентні лексеми-регіоналізми (афини, бесаги, бриндза, таджули, дримба, ізвори, кептар, кулеша, маслянка, полонина, смерека, чатиння, черес), а також частково еквівалентні (бадіки, дівчич, дітвак, нанашка, стариня; вберя, камізелька, кошуля; воречок, вуживка, маӥння, осбриви, патик; горнятко, дзбанок, келішок, корець; бусол, вивірка; гражда, оседок, яскиня; могла-бис, чула-с, вчинили-сте, прийшла-м, тримай'го, мо', ув обличчя). Регіоналізми знаходимо й у складі багатьох фразеологізмів: брати на кии, до дупи, ні на цаль, рублики гребти бесаzами тощо. 3-поміж них натрапляємо на слова, вирази, для адекватного сприйняття яких у читача повинні бути фонові знання про відповідні політичні та історичні періоди в житті галичан, стереотипи їхньої соціально-національної поведінки. Це ключові слова епохи (бандерівці, бандпідсобники, боївка, большевія, емгебе, енкаведе, криїка, полуторка, трудодні); формули мовного етикету, зокрема вітання, запрошення, подяка (Славайсу! Прошу ласкаво до моєї гражди! Прошу пана; Дяка вам уклінна), звертання (білий мій світе; дівчатка мої гожі; донцюю; любко, мій пане; моє коханє; мой молодице; мої панночки; нанашки дорогенькі; пане-товаришу), лайка - у вигляді відверто дерогативної лексики та фразеології (лямва, макаронники, москалі, німаки, чубарики; курва, лахудра, наволоч, ненависний шваб, підстилка, відьма правдива, сексотка енкаведистська, скурвий син; холєра ясна, бодай тебе иляк трафив! до дідьчої мами, до дупи, хай ня смерека втне!). У виокремлених групах прикладів помітний зв'язок галичан з культурою і релігією представників інших народів (поляків, німців, євреїв), з якими українці західного регіону тривалий час органічно співіснували й перебували в єдиному ідеологічному та культурному просторі.

Ментальна модель художнього тексту передбачає окреслення національно зумовлених ціннісних орієнтирів автора. Важливим носієм національнокультурної інформації у Р. Федоріва є ономастика, супроводжувана краєзнавчими асоціаціями. Художній простір письменник прив'язує до реального простору Прикарпаття й Гуцульщини. Автор не просто зосереджується на такому обмеженому локусі, а хоче показати самодостатній, окремий світ краян зі своїми законами, взаємозв'язками, що існує в просторі й часі, в якому закодовано людські таємниці й світові трагедії, людей, які наблизились до розгадки найбільших тайн, як-от: існував нібито Золотий вік, коли люди жили у злагоді з меншими братами ... розуміли мову звірів і птахів, шепіт трав $і$ шелест дерев... ие була, мабуть, єдина гармонійна мова любові <...> ...начебто ворожнеча зро-

\footnotetext{
${ }^{15}$ Р. Ф е д о р і в, зазн. джерело, № 3, с. 20.
} 
дилася пізніше ... до ворожнечі спонукав голод: все живе мусіло живитись живим $^{16}$. У повісті він згадує міста Коломию, Станіслав, Львів, річку Дністер, гори Карпати, однак домінуючим топосом залишається мала батьківщина - Тисменщина, якою він милується: ...душа його багатіла радістю повернення додому, до полів, до лісів, і він, дивуючись з самого себе, із закодованих комірок пам'яті, називав Оксані імена урочищ: ось Лази, ось Рудки, ось Вовчі Кути, ось Підпечари, а ось тут, у лісі, щзо зветься Монастирським, подивись-но на рештки мурів щзе з княжих часів монастиря, який зветься Богородиия на криниці, а ось изей пагорб розкопували перед війною... ${ }^{17}$.

Знання національних мовних багатств дозволяє митцеві дібрати потрібні слова, вирази для найповнішої передачі думки. Р. Федорів створив у повісті систему особових маркерів, репрезентованих перифразами (вищі кашкети місцева влада, гірський Дід - чаклун, лісові хлопиі - бандерівці, підпалений пожарищем сонияя - закоханий, широкі плечі в районі - владні покровителі), евфемізмами (антипко, крилатий лилик, нечистий, рогате створіння, чорний рогатий з пекла, щзезник із пекла - чорт; дідушок з чорним котом, зелейник, характерник - гірський чаклун; Чугайстер, Він, Пан над повзучою худобою - гірські міфічні істоти), вульгаризмами (лящва, макаронники, москалі, німаки, чубарики).

Почуття, настрої, уявлення про світ як власні, так і персонажів, Р. Федорів передає за допомогою „кольорових” тропів, що не випадково. Доведено, що колірний символізм відповідає мовнокультурним параметрам кожного народу. Нерідко в повісті семантика кольорів нейтралізована і в кольороназви з'являється виразний емоційно-оцінний зміст - позитивний чи негативний. Напр., на позначення чогось поганого, страшного, недоброго найчастіше вживаються червоний, чорний, коричневий (рудий) кольори: чорна наука; чорний розпач; вітер чорний, глухий; Слово було викричане чорне в чорну годину; чорні конвульсї коріння; скрик відбився від води і вдарив червоно; голос різкий, скрипучий, але й червоний, рудий; коричневий в'язкий сморід. У сполученнях на зразок сіра нудьга, сірий попіл сутінків, сіра мряка за рахунок відповідної кольороназви виникає почуття безвиході, безперспективності. Засобом поетизації предметних і абстрактних понять стають білий, голубий, срібний та волошковий кольори: біла тиша, голуба чаша неба, срібна вода, срібний лет павутиння, волошковий вогонь очей. Уява письменника може концентруватися на несподіваності ментальних асоціацій і тоді виникають оригінальні „колірні” прикметники: горіхо$\boldsymbol{в а ~ з а с м а г а ; ~ о ч і ~ ж о в т і , ~ а л е ~ и ̆ ~ ж с о л у д е в і ; ~ п о в і н ь ~ г о л у б а , ~ а л е ~ и ̆ ~ р а и ̆ д у ж н н а , ~ м е д в я н а . ~}$ Пейзажні замальовки в повісті (у трьох частинах твору нараховано їх близько двох десятків) часто базуються на кольоропозначеннях. Ось один із прикладів: Осінь стояла, як зріла жінка з обічяючим, манливим усміхом на губах - усміх іï золотився, як золотиста соломинка - щзодня зваблювала нас сонцем, яке викочувала, мов вогнене коло на безхмарне небо, червоними кетягами калини, срібними гойдалками павутиння... ${ }^{18}$. Подібні описи ніби слугують ще одним поясненням жанру повісті - триптих. Адже ця дефініція вживається здебільшого стосовно творів образотворчого й поетичного мистецтва. Кожну частину повісті Р. Федоріва можна сприймати як образки життя галичан.

\footnotetext{
${ }^{16}$ Там само, № 4, с. 10 .

${ }^{17}$ Там само, № 3, с. 14.

18 Там само, с. 26.
} 
Крім цього, привертають увагу картинні антропо- чи зооморфічні метафори, порівняння, що поєднуються в контексті, переливаються одне в одне, створюють поетичний тон і багатошаровий художній образ, позначений яскраво вираженим національним колоритом: Літо відступало з гірських хребтів крокпоза-крок, ліниво перечікуючи студені пориви вітрів та все ще потаємно сподіваючись, щьо завтра-післязавтра воно повернеться на свої полонини;смерекові ліси темніли, хмурилися і повнилися щземливим сумом; поодинокі гаджуги, гінкі й грайливі, мов дівчатка-підлітки, то тут, то там вибігали з тісного лісового гурту на изаринки й, занурившись з головою у сонячне літепло, завмирали на місиі, ледь-ледь ворушачи гіллям у солодкій дрімоті. Немов навмисне похудожницькому безладно розкидані на скошених изаринках осбриви отави були схожі на гострошоломних вартових, яким належало стерегти тут і тишу, $i$ замріяну лагідність, $i$ передосінній сум... ${ }^{19}$. Особливої експресії набувають порівняльні звороти, в яких об'єктом порівняння є найменування культурнопобутових реалій. Ці об’єкти різні, напр.: вливалося густе, як мед, сонячне світло; згаяний час колишеться, мов драглі; гостре лице було схоже на сокиру; потреба робити зло набубнявіє, як намочена квасолина; білява голівка, як квітка-ромашка; відчинив волохатий, мов джсміль, дідок; почувалася у лісі, немов у церкві; часи зблідли в пам'яті, як бузинове чорнило на папері; висока й суха, мов терлиця, жінка; у блакитному халатику, з розпущеною косою, щзо розсипалася по плечах, вона була схожа на ангела; настороженість, чорна й глибока, як дека скрипки та ін.

Неповторний дух й особливості мовної ментальності галичан, гуцулів маніфестують у творі локальні фразеологізми, на зразок: вода потекла на мій млин, дерти лаха, для кпинів, до честі, мати криту п'ятдесятку, не впорожні, ні на цзаль; біг пес через овес, ніщз не сталось ні псові, ні вівсові. Відповідно до власного образного сприйняття світу Р. Федорів оригінально видозмінює деякі звороти: зачиніть двері з того боку і манджайте додому; життя ніколи не гладить по голівці, якщо ти жнивеш на цій галілейській землі; не мати зеленого поняття; рублики гребти бесагами; $\boldsymbol{i}$ в пеклі добре приятеля мати; урвався, як гнила дратва, терпець; при вогні краще не згадувати; набратися емоцій, як бідному у торбу; прогнати з себе зайця.

В оповідях автор передає особливості усного мовлення своїх героїв, підкреслює характер слів, голосу, уживаючи різні образні засоби: голос змащений медом; медовий дискант; слова пекучі, жовчні; лебеділа ласкаво; цідив слова журливо; мову мала бистру; кожне слово, здавалося, вилущувала й сипала ними, мов горіхами; нанизувала слова густо тісно, одно тулила до другого, аж скручувала їх у сурову начебто нитку, і ще на додаток кожне слово огортала в шовк, у єдваби, щоб вони зовні виглядали ніжними; мовлене нею слово несподівано золотилося сонячним світлом ... слова ї̈ ... пахли конваліями; пісна бесіда; розмова сльозилася повільно; сукала бесіду гладко. Письменник фіксує специфічні способи спілкування персонажів. Напр., привертає увагу епізодичний образ польки Яніни з ії українсько-польською побутовою двомовністю: To $\epsilon$ великий секрет, прошу вас, про який вже всі знають: нині ввечері має приитти до мене на рантку мій Генріх. Тому мушу вигльондаць слічною і молодою ${ }^{20}$ Ментальна здатність відчувати таїнство Слова, його чар, могуть відтворено в образі гуцула-зелейника, який розуміє духовну енергію Слова, хоч і не розгадав

\footnotetext{
${ }^{19}$ Там само, № 4 , с. 7

${ }^{20}$ Там само, с. 32 .
} 
феномен мови. Він розмірковує: Тільки словом можна відмикати душі для добра, і лише словом можна боротися за добро ${ }^{21}$. Осмислення буття, життєвий досвід робить галичан справжніми філософами. Завдяки висловленим ними узагальненням, сентенціям розглядана повість має нескінченну глибину смислів, демонструє динаміку людської думки, відтворює переживання на рівні ментального світовідчуття. Наведемо кілька прикладів: Щастя - як пташка на плечі: пантруй, не сполохни; Жіноча душа - це не тільки спрага кохання, вона також безмежно підозріла, безмежно мстива й страждальна безодня, щзо постійно очікує зради; Ревність - непевність, щзо тебе кохають, підозріння, щуо думаєш і жадаєш іншого чи іншої; Мелодія, як запах відомого з наших літописів євщану, повертає забудькам пам'ять, піднімає ї̈ з найглибшого дна $i$ дає крила; Заздрість завжди люта, заздрість на зло здатна; Нічого на цчьому світі не пропадає: ні добро, ні зло. Рід відповідає за скоєне прадідами; Зло, вчинене одного разу, множиться багатократно; Зло незнищенне: воно вічне, воно саме з себе відроджується, множиться.

На прикладі аналізованої повісті можна стверджувати, що Р. Федорів належав до тих креативних письменників, які руйнували крайню зматеріалізованість української літератури XX ст. Він поєднав у поліфонічній оповіді міфологічну пам'ять, релігійні уявлення, показав узаємодію кількох пластів реальної дійсності й пояснив це насамперед національним буттям, українською ментальністю. Завдяки творчості Р. Федоріва поглиблюється розуміння цінності кожної національної мови й культури у світі.

Отже, в характеристиці художнього тексту як ментального утворення ключовими словами повинні бути мовленнєво-розумовий продукт, індивідуальна мовна форма вторинного відображення дійсності, специфічно авторське віддзеркалення світу.

${ }^{21}$ Там само, c. 9. 